\title{
EFFECT OF CHEMICAL FERTILIZATION, BIOFERTILIZER AND THIDIAZURON ON GROWTH AND YIELD OF ANISE (PIMPINELLA ANISUM L.) \\ BY
}

\author{
M. K. Khalil ${ }^{1}$, G. M. Ghazal ${ }^{2}$, A. Mahmoud ${ }^{1}$, D. A. Sallam ${ }^{2}$ \\ FROM \\ ${ }^{1}$ Plant Physiology section, Agric. Bot. Dept. Faculty of Agriculture, Cairo University, \\ Giza, Egypt. \\ ${ }^{2}$ Department of medicinal plant and natural products, National Organization for Drug \\ Control and Research, Giza, Egypt.
}

\begin{abstract}
This study was conducted during two successive seasons of 2012-2013 and 2013-2014 at Biotechnology Department, Phytochemistry Department and Farm of Applied Research Center of Medicinal Plants (ARCMP) affiliated to the National Organization for Drug Control And Research (NODCAR). The present work aimed to investigate the effect of inoculation Pimpinella anisum L. seeds with arbuscular mycorrhizal fungi (my) and/or microbein (mi) biofertilizer and foliar spray plants with Thidiazuron (TDZ) combined with chemical fertilizer at half or full dose of NPK on number of spores Am fungi $\left(\mathrm{kg}\right.$ soil $\left.^{-1}\right)$, AM fungi colonization, enzymatic activities (dehydrogenase activity [ $\mu \mathrm{g} \mathrm{TPF} / \mathrm{g}$ dry soil/day] \& Nitrogenase activity [nmol $\mathrm{C}_{2} \mathrm{H}_{4} / \mathrm{g}$ rhizosphere/ hour]), growth parameters (fresh weight of shoots per plant ( $\mathrm{g}$ ), fresh weight of roots per plant $(\mathrm{g})$, dry weight of shoots per plant $(\mathrm{g})$, dry weight of roots per plant $(\mathrm{g})$, Plant height $(\mathrm{cm})$, number of umbel per plant [at full flowering stage] \& dry weight of seeds per plant [at harvest stage]) and chemical composition (plant pigments [chlorophyll a, chlorophyll $\mathrm{b}$ and carotenoides], macro elements content (\%), total carbohydrates, and crude protein). The results in both seasons showed that, the highest values of number of AM fungi spores $\left(\mathrm{kg} \mathrm{soil}^{-1}\right)$ in anise (Pimpinella anisum $\mathrm{L}$.) roots, AM fungi colonization $\%$, enzymatic activities, growth parameters and chemical composition obtained at inoculating seeds with mixture of mycorrhizal and mycrobein at full dose of NPK.
\end{abstract}

\section{Introduction}

Anise (Piminella anisum L.) is belonging to the family of Apiaceae (Umbelliferae). Anise plant reaches a maximum height of $30-70 \mathrm{~cm}$ with ternately pinnate leaves. Very small and white flowers are born in compound umbels which distributed into 7 to 15 rays. The leaves of anise plant at the basal part are simple, 1.3$5.1 \mathrm{~cm}$ long and shallowly lobed, while leaves top on the stems are feathery pinnate divided into numerous leaves (Chevallier, 1996). The fruit of anise is pyriform or ovoid laterally compressed, 3-5 $\mathrm{mm}$ in length and 2-3 $\mathrm{mm}$ wide. The color of anise fruits is greyish-green to greyish-brown with a sweet smell. Every fruit contains two carpals both containing an aniseed. The seed is small and curved, about $0.5 \mathrm{~cm}$ long and greyish-brown. The pericarp is broadly ovoid, five ridged with short hairs and various vittae (Ross 2001). The essential oil is located in the schizogenic oil ducts of anise fruits, and shoots (Figueiredo et al., 2008). Aniseeds contain 1.5-5\% essential oil and 
used as flavouring, digestive, carminative, and relief of gastrointestinal spasms. Consumption of aniseed in lactating women increases milk and also reliefs their infants from gastrointestinal problems (Zargari, 1996). In the food industry, anise is used as flavoring and aromatic agent for fish products, ice cream, sweets, and gums (Özcan and Chalchat, 2006 \& Salehi, 2010 ).

Biofertilizers are the products containing living cells of different types of microorganisms which have the ability to mobilize nutritionally important elements from a non-usable to a usable forms through biological processes. Although the advent of the phenomenon is more than a century old, the need of its commercial exploitation was not applied (Saber, 1993 ; Hegde et al, 1999). Microorganisms play an important role in various chemical transformations of soils and thus, influence the availability of major nutrients like nitrogen, phosphorus, potassium and sulphur to the plants. Cyanobacteria and phosphate-solubilizing bacteria were used as biofertilizers to increase crop production (Singh, et al 1997; Earanna and Govindan, 2002).

Biofertilizers, however, have no toxic effects. Biofertilizers are commonly called as microbial inoculants which are capable of mobilizing important nutritional elements in the soil from non-usable to usable form by the crop plants through their biological processes. For the last decade, biofertilizers are used extensively as an eco-friendly approach to minimize the use of chemical fertilizers, improve soil fertility status and for enhancement of crop production by their biological activity in the rhizosphere (Contra costa, 2003, Patil, 2010). Chemical fertilizers are expensive, they disturb the equilibrium of agro-ecosystems and cause pollution to the environment. These problems may be avoided by the use of biofertilizers (Al-Khiat, 2006).

Thidiazuron (N-phenyl-N'- 1,2,3,- thiadiazol-5-ylurea), is a synthetic diphenylurea (DPU) type cytokinin that is thought to encourage the synthesis and /or accumulation of purine type cytokinins (Thomas and Katterman, 1986). In agriculture, TDZ is used as a defoliant particularly in cotton. It is sprayed on a field to defoliate the plants before the boll harvest.

Khafaga and Abd-Elnaby (2007) on four wheat cultivars under different foliar application $\left(0.1 \% \mathrm{ZnSO}_{4}, 20 \mathrm{ppm}\right.$ paclobutrazol, $2.0 \mathrm{ppm}$ Thitiazuron (TDZ) and tap water) reported that, Sids1 cv. treated with TDZ produced the best development at tillering and harvesting stages. Concerning chemical composition, $2.0 \mathrm{ppb}$ TDZ treatment enhanced proline content, photosynthetic pigments, total carbohydrates, protein, $\mathrm{K}^{+}$and $\mathrm{Ca}^{++}$content in shoots of wheat plant as compared with the other treatments while the reverse was true for $\mathrm{Na}^{+}$content. the effects of nitrogen fertilizer and plant growth regulators (PGRs) on spiking studied by (Ichihashi et al.,2010), and they investigated that, TDZ stimulated vegetative or reproductive lateral bud growth markedly, depending on the air temperature.

The aim of the present work was to study the effect of my, mi and TDZ combined with half or full dose of NPK on growth, yield and chemical composition of anise plant.

\section{MATERIALS AND METHODS}

This work was carried out during two successive seasons 2012-2013 and 20132014 at Biotechnology Department, phytochemistry Department and Farm of Applied 
Research Center of Medicinal Plants (ARCMP) affiliated to the National Organization for Drug Control And Research (NODCAR).

\section{Plant material}

Seeds of Pimpinella anisum L. obtained from Harraz market for Seeds and Pesticides (Bab El Khalk square, Cairo, Egypt).

\section{microorganisms material:-}

1. Mycorrhizal (contains Gloums spp., Gigaspora spp. and Acaulospora spp. V 1:1:1) obtained from Soil, Water and Environment Research Institute.

2. Mycrobein (biofertilizer containing $\mathrm{N}$-fixing [such as Azotobacter and Azospirillum] and P-dissolving bacteria [Such as Pseudomonas and Bacillus megatheium] produced and distributed commercially by the General Organization for Agriculture Equalization Fund. Ministry of Agriculture, Egypt.

Mycorrhizal and microbein coated the seed of anise pre-planting by mixing with a fine mist of $10 \%$ sugar solution and mixing seed with the microbein and Mycorrhizal spores.

\section{Thiduazoran growth regulators} TDZ).

Obtained from commercial compound named Prop® 50 WP (containing 50\%

Plants were sprayed during vegetative growth (at 45 and 60 days after sowing) with $10 \mathrm{ml}$ of a solution containing $(5 \mathrm{mg} / \mathrm{l} \mathrm{TDZ}$ dissolving in water containing $0.01 \%$ tween 20) using a hand atomizer. Weighing the plants before and after spraying showed that approximately 5 to $7 \mathrm{ml}$ of the solution adhered to each plant. Control plants were sprayed with water containing $0.01 \%$ tween 20 but without TDZ.

\section{Soil used}

The soil used in the present work are collected the from farm of Applied Research Center soil of Medicinal Plants (ARCMP) related to The National Orgnization for Drug Control And Research (NODCAR) and initially analyzed for chemical and physical characters according to Black et al. (1965). These characters are presented in Table (1).

Table (1): Chemical and physical characteristics of the experimental soil

\begin{tabular}{|c|c|c|c|c|c|c|c|c|c|c|}
\hline $\begin{array}{c}\text { EC } \\
\text { mmohs } / \mathrm{cm}\end{array}$ & SP & $\mathrm{Ph}$ & \multicolumn{8}{|c|}{ Soluble ions $(\mathrm{meq} / \mathrm{L})$} \\
\hline \multirow[b]{2}{*}{7.5} & \multirow[b]{2}{*}{26} & \multirow[b]{2}{*}{8.1} & $\mathrm{Ca}^{++}$ & $\mathrm{Mg}^{++}$ & $\mathrm{Na}^{+}$ & $\mathrm{K}^{+}$ & $\mathrm{CO}_{3}{ }^{-}$ & $\mathrm{HCO}_{3}^{-}$ & $\mathrm{Cl}^{-}$ & $\mathrm{SO}_{4}^{-}$ \\
\hline & & & 8.10 & 9.32 & 2.57 & $\begin{array}{l}.8 \\
0\end{array}$ & ---- & 2.6 & 4.24 & 13.93 \\
\hline \multicolumn{11}{|c|}{ Some physical characteristics of the experimental soil } \\
\hline \multicolumn{7}{|c|}{ Particle size distribution $(\%)$} & \multicolumn{4}{|c|}{ Texture class } \\
\hline \multicolumn{2}{|c|}{$\begin{array}{c}\text { Coarse } \\
\text { sand }\end{array}$} & $\begin{array}{l}\text { Fine } \\
\text { sand }\end{array}$ & \multicolumn{2}{|c|}{ Silt } & \multicolumn{2}{|c|}{ Clay } & & \multirow{2}{*}{\multicolumn{2}{|c|}{ Sand clay }} & \\
\hline 47.15 & & 23.17 & & 9.91 & \multicolumn{2}{|c|}{9.77} & & & & \\
\hline
\end{tabular}




\section{Experimental design and layout}

The experiment was laid out in randomized block design (RBD) $(6 \times 7 \mathrm{~m})$ with 3 replications; each block was prepared to contain 10 rows, seeds were sowed at a plant density of 5 plants $\mathrm{m}^{2}$. Randomization of the treatments was done with the help of random number table as advocated by Fisher, 1950. The treatments were:-

1) Untreated plants with chemical and bio-fertilizer (zero).

2) Recommended dose of chemical fertilizer (control).

3) Recommended dose of chemical fertilizer + mycorrhizal

4) Recommended dose of chemical fertilizer + microbein

5) Recommended dose of chemical fertilizer + TDZ

6) Recommended dose of chemical fertilizer + mycorrhizal + microbein

7) Recommended dose of chemical fertilizer + mycorrhizal + TDZ

8) Recommended doses of chemical fertilizer + microbein + TDZ

9) Half recommended dose of chemical fertilizer.

10) Half recommended dose of chemical fertilizer + mycorrhizal

11) Half recommended dose of chemical fertilizer + microbein

12) Half recommended dose of chemical fertilizer + TDZ

13) Half recommended dose of chemical fertilizer + mycorrhizal + microbein

14) Half recommended dose of chemical fertilizer + mycorrhizal + TDZ

15) Half recommended doses of chemical fertilizer + microbein + TDZ

Recommended dose of chemical fertilizer were $200 \mathrm{~kg} /$ Fadden superphosphate $\left(12.5 \% \quad \mathrm{P}_{2} \mathrm{O}_{5}\right)$ added before planting, while the plants were fertilized with 200 $\mathrm{Kg} /$ Fadden ammonium sulphate $(20.6 \% \mathrm{~N})$ and $50 \mathrm{Kg} /$ Fadden potassium sulphate $\left(50 \% \mathrm{KO}_{2}\right)$ after 30 and 45 days from planting at two stage.

Seeds of anise planting in October and the harvest were in May.

The data recorded were:-

\section{Determination of number of spores Am fungi (kg soil ${ }^{-1}$ ) and AM fungi colonization}

The percentage of AM fungi colonization in plant root tissues was determined as described by Philips and Hayman (1970)

\section{Enzymatic activities determinations}

\section{a. dehydrogenase activity ( $\mu \mathrm{g}$ TPF/g dry soil/day)}

The dehydrogenase activity was estimated according to (Skujins and burns ,1976)

\section{b. Nitrogenase activity (nmol $\mathrm{C}_{2} \mathrm{H}_{4} / \mathrm{g}$ rhizosphere/ hour)}

The activity of nitrogenase enzyme was determined by the acetylene reduction technique according to Hardy et al (1973).

\section{Growth parameters}

The recorded data for the experiments at three periods (2 [December], 4 [February] and 6 [April] months) were as follows:

[fresh weight of shoots per plant (g), fresh weight of roots per plant $(\mathrm{g})$, dry weight of shoots per plant $(\mathrm{g})$, dry weight of roots per plant $(\mathrm{g})$, Plant height $(\mathrm{cm})$, number of 
umbel per plant (at full flowering stage) and dry weight of seeds per plant (at harvest stage)]

\section{Chemical composition}

\section{a. Determination of plant pigments}

Leaf samples were used to measure Chl. a , b (Arnon 1949) and Carotenoid contents (Lichtenthaler and Wellburn, 1983).

\section{b. Determination of total carbohydrates in the dried herb}

The content of total carbohydrates of the samples was determined by the phenol sulfuric acid method (Dubois et al., 1956 and Krishnaveni et al., 1984).

\section{c. Crude protein content (\%)}

Sample of anise leaves were analysed separately for nitrogen content (\%) by colorimetric method (Snell and Snell, 1949). Nitrogen content is multiplied with 6.25 factors to calculate crude protein content in head (A.O.A.C., 1960).

\section{d. Macro elements determination}

\section{Nitrogen}

Nitrogen content was determined by the modified micro-Kjeldahl method as described by Pregl, (1945).

\section{Phosphorus}

The phosphorus content was estimated after wet ashing by using molybdic acid to form phosphomlybdate complex, and then reduced with aminoaphthosulphuric acid to complex molybdenum blue which was measured calorimetrically (at $660 \mu \mathrm{m}$ ) using a standard curve of potassium dihydrogen phosphate as recommended by Murphy and Riley (1962).

\section{Potassium}

Potassium was determined using a flame photometer as described by (Jackson ,1965).

\section{Statistical analysis.}

Data recorded on vegetative growth and chemical compositions were statistically analyzed, and separation of means was performed using the least significant difference (L.S.D.) test at the 5\% level, as described by (Snedecor and Cochran, 1967).

\section{RESULTS AND DISCUSSIONS}

\section{Microbiological parameters}

\section{a) number of AM fungi spores (kg soil $\left.{ }^{-1}\right)$}

Data concerning the effect of treated anise (Pimpinella anisum L.) plant with chemical , bio-fertilizer and TDZ on number of AM fungi spores ( $\mathrm{kg}$ soil $^{-1}$ ) are presented in Table (2). Data showed that inoculation of anise (Pimpinella anisum L.) seeds with AM mycorrhizal led to significantly increase in number of AM fungi spores $\left(\mathrm{kg} \mathrm{soil}{ }^{-1}\right)$ compared to un-inoculated seeds. 
Also the data showed that the highest values of number of AM fungi spores ( $\mathrm{kg}$ soil $^{-1}$ ) were $3 \times 10^{4}$ and $3.2 \times 10^{4}$ in anise (Pimpinella anisum L.) roots obtained at inoculation of seeds with mixture of mycorrhizal and mycrobein at full dose of NPK in the first and second seasons, respectively.

These results were in accordance with the finding of Ramakrishnan and Bhuvaneswari (2014) on Eleusine coracana (L.) Gaertn, they investigated that combined inoculation of AM Fungi with Azospirillium and Azotobacter significantly increased number of AM spores in soil. In this connection Edyta et al. (2015) who concluded that treated strawberry with the bioproducts (mixture of AM fungi: Glomus species, Trichoderma viride, and rhizosphere bacterial species (Bacillus subtilis, Pseudomonas fluorescens and Streptomyces spp.) led to increase in the number of spores of AMF.

\section{b) AM fungi colonization \%}

Data presented in Table (3) showed the response of anise (Pimpinella anisum L.) to inoculation of seeds with biofertilizer and/or foliar plants with TDZ at half or full recommended doses of NPK. The obtained results reported that inoculating of anise (Pimpinella anisum L.) seeds with mycorrhizal led to significant increase in AM fungi colonization \% compared to uninoculated seeds.

Data also recorded that inoculation of anise (Pimpinella anisum L.) seeds with a mixture of mycorrhizal plus microbein at full recommended dose of NPK gave the highest values of AM fungi colonization \% were (93.25 and 94.82\%) scored at the first and second seasons, respectively, but the lowest values obtained by zero treatment were $(14.99 \%$ and $15.28 \%)$ scored at the first and second seasons, respectively.

Generally, the obtained results were in harmony with the finding of Ramakrishnan and Bhuvaneswari (2014) they found that combined inoculation of $A M$ Fungi with Azospirillium and Azotobacter significantly increased percent root colonization in roots of Eleusine coracana (L.) Gaertn . Soliman et al. (2015) they indicated that inoculation of Delonix regia seedling with biofertilizer (Arbascular mycorrhizal fungi, Azotobacter chroococum, yeast strains and mixture of all inoculums) led to significant increase in AM fungi colonization \% compared to the un-inoculated seedlings at the recommended dose of NPK chemical fertilizers under the same condition.

\section{Dehydrogenase activity ( $\mu$ g TPF/g dry soil/day)}

Table (4) proved the extended effect of chemical, bio-fertilizer and TDZ on dehydrogenase activity ( $\mu \mathrm{g} \mathrm{TPF} / \mathrm{g}$ dry soil/day) in rhizosphere of anise (Pimpinella anisum L.) plant. The obtained results showed that inoculation of anise (Pimpinella anisum L.) seeds with a mixture of mycorrhizal plus microbein at full recommended dose of NPK gave the highest values of dehydrogenase activity ( $\mu \mathrm{g}$ TPF/g dry soil/day) were (115.6 and 119.96 ) scored at the first and second seasons respectively compared to control and other treatments. On the other hand, the lowest values obtained by zero treatment were (21.00 and 25.28) scored at the first and second seasons respectively.

These results were in accordance with the findings of Amal et al. (2014) revealed that dehydrogenase activity ( $\mu \mathrm{g}$ TPF/100 $\mathrm{g}$ soil Day $^{-1}$ ) under different inoculation treatments of Thiobacillus A1, A2 and/or AM fungi were higher than those 
of un inoculated treatments, after 60 and 90 days of planting. In this respect, Haddad et al. (2014) showed that the highest significant increase in percentages of enzyme activity (dehydrogenase) was recorded in the treatment inoculated Eucalyptus camaldulensis with the mixed microbial treatment (Azotobacter chroococcum, Bacillus circulans and Arbuscular mycorrhizal fungi AMF) a rather than that of individual and dual treatments in two seasons.

\section{Nitrogenase activity (nmol $\mathrm{C}_{2} \mathrm{H}_{4} / \mathrm{g}$ rhizosphere/ hour)}

Data concerning the effect of chemical, bio-fertilizer and TDZ on nitrogenase activity (nmol $\mathrm{C}_{2} \mathrm{H}_{4} / \mathrm{g}$ rhizosphere/ hour) in rhizosphere of anise (Pimpinella anisum L.) plant are presented in Table (5). Data showed that inoculation of anise (Pimpinella anisum L.) seeds with microbein led to significantly increase of nitrogenase activity (nmol $\mathrm{C}_{2} \mathrm{H}_{4} / \mathrm{g}$ rhizosphere/ hour) compared to control or other treatments.

Also the data cleared that the highest values of nitrogenase activity were (530.97 and $541.08 \mathrm{nmol} \mathrm{C}_{2} \mathrm{H}_{4} / \mathrm{g}$ rhizosphere/ hour) obtained with inoculation of anise (Pimpinella anisum L.) seeds with a mixture of mycorrhizal plus microbein at full recommended dose of NPK scored at the first and second seasons respectively, but the lowest values obtained by zero treatment were (78.96 and 80.00) scored at the first and second seasons respectively.

These results were in agreement with the findings of Hadad et al. (2014) They showed that the highest significant increase in percentages of enzyme activity (nitrogenase) was recorded in the treatment inoculated Eucalyptus camaldulensis with the mixed microbial treatment (Azotobacter chroococcum, Bacillus circulans and Arbuscular mycorrhizal fungi AMF) a rather than that of individual and dual treatments in two seasons. Nitrogenase activity $\left(\mathrm{N}_{2}\right.$-ase) was used as a criterion of atmospheric nitrogen fixation by diazotrophs. Three different types of nitrogen fixing bacteria viz, Azotobacter vinelandii, Paenibacillus polymyxa and Pseudomonas fluorescens were isolated from rhizosphere of field-grown sugarcane in Barak Valley, Assam.

\section{Growth parameters}

As for the effect of chemical, bio-fertilizer and TDZ on [fresh weight of shoots per plant $(\mathrm{g})$, fresh weight of roots per plant $(\mathrm{g})$, dry weight of shoots per plant $(\mathrm{g})$, dry weight of roots per plant $(\mathrm{g})$, Plant height $(\mathrm{cm})$, number of umbel per plant (at full flowering stage) and dry weight of seeds per plant (at harvest stage)], the obtained results in Tables $(6,7,8,9,10,11$ and12) indicated that all treatments significantly increased growth parameters as compared to zero in two season.

Data also showed that the highest values of growth parameters [fresh weight of shoots per plant $(29.67,83.62$ and $145.12 \mathrm{~g} / \mathrm{plant})$, fresh weight of roots per plant (3.26, 6.78 and $9.8 \mathrm{~g} / \mathrm{plant})$, dry weight of shoots per plant (4.44, 13.0 and 23.73 $\mathrm{g} /$ plant), dry weight of roots per plant $(0.55,1.13$ and $1.95 \mathrm{~g} / \mathrm{plant})$, Plant height (31.27, 58.25 and $82.22 \mathrm{~cm}$ ), number of umbel per plant (113.63) and dry weight of seeds per plant $(48.72 \mathrm{~g} /$ plant $)]$ obtained by treated anise plants with full NPK plus mycorrhizal and microbein at three periods (2, 4 and 6 months) during in the first season.

However, the lowest values of growth parameters [fresh weight of shoots per plant $(8.06,19.33$ and $40.52 \mathrm{~g} / \mathrm{plant})$, fresh weight of roots per plant (1.23, 2.75 and $4.55 \mathrm{~g} /$ plant $)$, dry weight of shoots per plant $(0.83,3.93$ and $8.25 \mathrm{~g} / \mathrm{plant})$, dry weight of 
roots per plant $(0.22,0.44$ and 0.80$)$, Plant height $(10.00,18.80$ and $30.57 \mathrm{~cm})$, number of umbel per plant (20.4) and dry weight of seeds per plant $(11.5 \mathrm{~g} / \mathrm{plant})]$ obtained by zero treatment at three periods (2, 4 and 6 months) during in the first season. The obtained results from the second season hold true for those of the first season.

The results were in accordance with the finding of Kundu et al. (2011) reported that all the inorganic and biofertilizer combinations exhibited profound effect on growth, yield and fruit quality than inorganic fertilizer alone on pruned mango orchard cv. Amrapali , and concluded that the treatments 100\% NPK + Azotobacter + VAM and $75 \%$ NPK + Azotobacter + VAM were effective and may be adopted to improve the vegetative growth and productivity with quality fruits. In this respect, Harb et al., (2011) on Nigella sativa L. plants, indicated that the biofertilization (Glomus macrocarpus fungus or Nitrobein bacteria) or organic manure alone or in combination with half or full NPK fertilizer increased plant height $(\mathrm{cm})$, No. of branches and leaves, root length $(\mathrm{cm})$ as well as herb and root dry weight when compared with un inoculated plants (control). Also, the best significant results of herb and root dry weight were found with mycorrhizal fungus and Azotobacter with full NPK fertilizers treatment as compared to the other treatments under study. Also, G. macrocarpus fungus+Nitrobein+organic manure with full NPK fertilizer treatment were more effective in increasing the seed yield per plant and fadden than the other treatments under study.

Similar results were recorded by Singh et al. (2011) recorded that treated stevia (Stevia rebaudiana Bertoni) with $100 \%$ NPK + Azotobactor gave higher fresh and dry herb yield per hectare as compared to other treatment combinations. In this respect, Agamy et al., (2012) showed that the application of Bio and/or FM in combination with NPK on wheat (Triticum aestivum L.) significantly increased all growth characters i.e., plant height, number of spikes/plant, leaf area and fresh and dry weights of both shoot and spikes / plant. These results agree with the finding of El-Aal and El-Rahman (2014) found that, the best results of vegetative growth on sweet ananas melon plant, photosynthetic pigments content total fruiting/plant and chemical composition of leaves and fruits were obtained with the application of biofertilizer+full chemical fertilization dose. In this connection, Soliman et al . (2015) indicated that inoculation of Delonix regia seedlings with bio-fertilizers (Arbascular mycorrhizae fungi, Azotobacter chroorcoccum, yeast strains and mixture of all inoculum) led to significant increase in growth characters (plant height, root length, number of branches/plant, total fresh and dry weights/plant), microbial populations and AM fungi colonization (\%), enzymatic activities, compared to the un-inoculated seedlings (as control) at the recommended dose of NPK chemical fertilizers under the same conditions.

\section{Effect of chemical, bio-fertilizer and TDZ on chemical composition of Pimpinella anisum L. plant}

Data concerning the effect of inoculation Pimpinella anisum L. seeds with mycorrhizal and/or microbein and sprayed plants with TDZ combine chemical fertilizer at half or full dose of NPK on plant pigments [chlorophyll a, chlorophyll $b$ and carotenoides], total carbohydrates, crude protein, content (\%) and Macro elements are presented in Tables (13-20).

Data showed that inoculation Pimpinella anisum L. seeds with mixture of mycorrhizal and microbein at full dose of NPK gave the highest values of plant 
pigments [chlorophyll a were $(0.74,1.31$ and 1.85$)$ chlorophyll $\mathrm{b}(0.21,0.35$ and 0.56$)$ and carotenoides $(0.53,0.72$ and 1.00)], total carbohydrates (42, 49 and 56\%), crude protein $(13.75,18.75$ and 23.13\%), and Macro elements (nitrogen [2.2, 3.00 and 3.7\%] , phosphorus [0.42, 0.65 and $0.71 \%]$, potassium [1.90, 2.60 and 3.39\%]) at three periods (2, 4 and 6 months) in the first season. On the other hand, zero treatment gave the lowest values of plant pigments [chlorophyll a were $(0.20,0.39$ and 0.50$)$ chlorophyll $b(0.05,0.10$ and 0.15$)$ and carotenoides $(0.15,0.21$ and 0.32$)]$, total carbohydrates (22, 24 and 27\%), crude protein (13.75, 18.75 and 23.13\%), and Macro elements (nitrogen [0.75, 0.90 and 1.13\%], phosphorus [0.10, 0.16 and $0.2 \%$, potassium $[(0.64,0.82$ and $1.00 \%])$ at three periods $(2,4$ and 6 months $)$ in the first season. The obtained results from the second season hold true for those of the first season.

Suke et al. (2011) reported that treated maize (Zea mays L. ) with recommended dose fertilizer + Azotobacter + PSB led to increased in chlorophyll content ,nitrogen, phosphorus and potassium content in leaves, Protein and starch content in grain. The NPK-bacterial fertilizer combinations influenced positively the educed phosphorus and potassium by ryegrass (Lolium perenne L.). plant, these results were reported by (Jakab et al., 2011). El-Quesni et al. (2013) reported that chlorophyll a, b and carotenoids were increased with mixed biofertilizers application. Total carbohydrates content significantly increased in leaves and roots of Jatropha seedlings treated with phosphorien, microbien. Such increment in photosynthetic pigments, which reflect in photosynthesis processes and led to increase in carbohydrate contents.

El-Aal and El-Rahman (2014) found that the best results of photosynthetic, pigments content, total fruiting/plant and chemical composition of leaves and fruits on sweet ananas, melon plant, were obtained with the application of biofertilizer+full chemical fertilization dose. Soliman et al . (2015) showed that inoculation Delonix regia seedlings with bio-fertilizers (Arbascular mycorrhizae fungi, Azotobacter chroorcoccum, yeast strains and mixture of all inoculums) led to significant increase chemical composition (plant pigments, total carbohydrates, proline content, N, P, K) besides antioxidant enzymes such as catalase (CAT), and peroxidase (POD) compared to the un-inoculated seedlings (as control) at the recommended dose of NPK chemical fertilizers under the same conditions. 
Table 2. Effect of chemical fertilization, biofertilizer and TDZ on mean number of spores $\left(\mathrm{Kg}\right.$ soil $\left.^{-1}\right)$ after 50 days of planting anise during 2012/2013 and 2013/2014 seasons.

\begin{tabular}{|c|c|c|c|}
\hline \multirow{2}{*}{ Treatment } & \multicolumn{2}{|c|}{ Growing season } & \multirow[b]{2}{*}{ Mean } \\
\hline & 2012-2013 & 2013-2014 & \\
\hline Zero & $0.72 \times 10^{4}$ & $0.75 \times 10^{4}$ & $0.74 \times 10^{4}$ \\
\hline full dose & $0.90 \times 10^{4}$ & $0.98 \times 10^{4}$ & $0.94 \times 10^{4}$ \\
\hline full + my & $2.70 \times 10^{4}$ & $2.80 \times 10^{4}$ & $2.75 \times 10^{4}$ \\
\hline full + mi & $1.17 \times 10^{4}$ & $1.20 \times 10^{4}$ & $1.19 \times 10^{4}$ \\
\hline full + TDZ & $0.90 \times 10^{4}$ & $0.90 \times 10^{4}$ & $0.90 \times 10^{4}$ \\
\hline $\mathrm{full}+\mathrm{my}+\mathrm{mi}$ & $3.00 \times 10^{4}$ & $3.20 \times 10^{4}$ & $3.10 \times 10^{4}$ \\
\hline full + my + TDZ & $2.70 \times 10^{4}$ & $2.82 \times 10^{4}$ & $2.76 \times 10^{4}$ \\
\hline full + mi + TDZ & $1.20 \times 10^{4}$ & $1.29 \times 10^{4}$ & $1.25 \times 10^{4}$ \\
\hline half dose & $0.78 \times 10^{4}$ & $0.80 \times 10^{4}$ & $0.79 \times 10^{4}$ \\
\hline half + my & $1.90 \times 10^{4}$ & $1.95 \times 10^{4}$ & $1.93 \times 10^{4}$ \\
\hline half + mi & $1.00 \times 10^{4}$ & $1.00 \times 10^{4}$ & $1.00 \times 10^{4}$ \\
\hline half + TDZ & $0.80 \times 10^{4}$ & $0.89 \times 10^{4}$ & $0.85 \times 10^{4}$ \\
\hline half $+\mathrm{my}+\mathrm{mi}$ & $2.10 \times 10^{4}$ & $2.20 \times 10^{4}$ & $2.15 \times 10^{4}$ \\
\hline half + my + TDZ & $1.90 \times 10^{4}$ & $2.00 \times 10^{4}$ & $1.95 \times 10^{4}$ \\
\hline half + mi + TDZ & $1.00 \times 10^{4}$ & $1.00 \times 10^{4}$ & $1.00 \times 10^{4}$ \\
\hline Mean & $1.52 \times 10^{4}$ & $1.59 \times 10^{4}$ & \\
\hline
\end{tabular}

Table 3. Effect of chemical fertilization, biofertilizer and TDZ on mean mycorhhizal colonization (\%)after 50 days of planting anise during 2012/2013 and 2013/2014 seasons.

\begin{tabular}{|c|c|c|c|}
\hline \multirow{2}{*}{ Treatment } & \multicolumn{2}{|c|}{ Growing season } & \multirow[b]{2}{*}{ Mean } \\
\hline & 2012-2013 & 2013-2014 & \\
\hline Zero & 14.99 & 15.28 & 15.14 \\
\hline full dose & 22.81 & 25.00 & 23.91 \\
\hline full + my & 87.23 & 89.08 & 88.16 \\
\hline full $+\mathrm{mi}$ & 35.00 & 35.92 & 35.46 \\
\hline full + TDZ & 25.08 & 26.89 & 25.99 \\
\hline full + my + mi & 93.25 & 94.82 & 94.04 \\
\hline full + my + TDZ & 88.55 & 89.93 & 89.24 \\
\hline full + mi + TDZ & 38.22 & 40.00 & 39.11 \\
\hline half dose & 17.50 & 18.88 & 18.19 \\
\hline half + my & 65.29 & 68.07 & 66.68 \\
\hline half $+\mathrm{mi}$ & 31.00 & 32.90 & 31.95 \\
\hline half + TDZ & 20.00 & 22.00 & 21.00 \\
\hline half $+\mathrm{my}+\mathrm{mi}$ & 75.00 & 75.78 & 75.39 \\
\hline half + my + TDZ & 67.33 & 70.00 & 68.67 \\
\hline half + mi + TDZ & 33.87 & 35.82 & 34.85 \\
\hline Mean & 47.67 & 49.36 & \\
\hline
\end{tabular}


Table 4. Effect of chemical fertilization, biofertilizer and TDZ on mean nitrogenase activity (nmo $\mathrm{C}_{2} \mathrm{H}_{4} / \mathrm{g}$ rhizosphere/hour) after 50 days of planting anise during 2012/2013

and 2013/2014 seasons.

\begin{tabular}{cccc}
\hline Treatment & \multicolumn{2}{c}{ Growing season } & Mean \\
\cline { 2 - 3 } Zero & $2012-2013$ & $2013-2014$ & 79.48 \\
full dose & 78.96 & 80.00 & 167.88 \\
full + my & 165.80 & 169.96 & 264.76 \\
full + mi & 260.72 & 268.80 & 468.10 \\
full + TDZ & 465.00 & 471.20 & 142.50 \\
full + my + mi & 140.00 & 145.00 & 536.03 \\
full + my + TDZ & 530.97 & 541.08 & 292.13 \\
full + mi + TDZ & 289.25 & 295.00 & 484.47 \\
half dose & 482.27 & 486.66 & 102.40 \\
half + my & 100.95 & 103.85 & 214.44 \\
half + mi & 210.00 & 218.87 & 392.86 \\
half + TDZ & 389.98 & 395.74 & 127.90 \\
half + my + mi & 125.92 & 129.88 & 424.33 \\
half + my + TDZ & 420.80 & 427.85 & 239.89 \\
half + mi + TDZ & 237.77 & 242.00 & 402.64 \\
Mean & 400.21 & 405.07 & 292.06 \\
\hline Tab & 286.57 &
\end{tabular}

Table 5. Effect of chemical fertilization, biofertilizer and TDZ on mean dehydrogenase activity ( $\mu$ g TPF/g dry soil/day) after 50 days of planting anise during 2012/2013 and 2013/2014 seasons.

\begin{tabular}{cccc}
\hline Treatment & \multicolumn{2}{c}{ Growing season } & Mean \\
\cline { 2 - 4 } Zero & $2012-2013$ & $2013-2014$ & 23.14 \\
full dose & 21.00 & 25.28 & 71.78 \\
full + my & 70.00 & 73.55 & 90.46 \\
full + mi & 88.92 & 92.00 & 83.39 \\
full + TDZ & 81.72 & 85.05 & 71.27 \\
full + my + mi & 69.22 & 73.32 & 117.78 \\
full + my + TDZ & 115.60 & 119.96 & 106.12 \\
full + mi + TDZ & 103.37 & 108.87 & 100.35 \\
half dose & 98.92 & 101.77 & 32.90 \\
half + my & 30.80 & 35.00 & 53.95 \\
half + mi & 52.00 & 55.89 & 51.84 \\
half + TDZ & 50.72 & 52.96 & 40.12 \\
half + my + mi & 38.87 & 41.37 & 72.43 \\
half + my + TDZ & 70.00 & 74.85 & 64.91 \\
half + mi + TDZ & 63.38 & 66.44 & 60.32 \\
Mean & 58.55 & 62.09 & 71.23 \\
\hline
\end{tabular}


Table 6. Effect of chemical fertilization, biofertilizer and TDZ on mean fresh weight of shoots (g/plant) of anise plant during 2012/1013 and 2013/2014 seasons.

\begin{tabular}{|c|c|c|c|c|c|c|c|c|}
\hline \multirow{4}{*}{ Treatment (A) } & \multicolumn{8}{|c|}{ Growing season } \\
\hline & \multicolumn{4}{|c|}{$2012-2013$} & \multicolumn{4}{|c|}{$2013-2014$} \\
\hline & \multicolumn{8}{|c|}{ Sampling data (month) (B) } \\
\hline & 2 & 4 & 6 & Mean & 2 & 4 & 6 & Mean \\
\hline Zero & 8.06 & 19.33 & 40.52 & 22.64 & 9.58 & 23.00 & 48.09 & 26.89 \\
\hline full dose & 20.00 & 60.13 & 102.82 & 60.98 & 21.87 & 67.55 & 115.97 & 68.46 \\
\hline full + my & 24.09 & 70.89 & 120.72 & 71.90 & 25.98 & 74.38 & 135.07 & 78.48 \\
\hline full + mi & 22.00 & 68.00 & 115.27 & 68.42 & 24.73 & 72.00 & 130.75 & 75.83 \\
\hline full + TDZ & 20.50 & 66.39 & 112.00 & 66.30 & 23.57 & 69.00 & 120.69 & 71.09 \\
\hline full + my + mi & 29.67 & 83.62 & 145.12 & 86.14 & 33.78 & 90.85 & 157.25 & 93.96 \\
\hline full + my + TDZ & 26.74 & 76.80 & 133.00 & 78.85 & 28.57 & 82.67 & 146.33 & 85.86 \\
\hline full + mi + TDZ & 25.08 & 74.77 & 128.55 & 76.13 & 27.97 & 78.81 & 143.52 & 83.43 \\
\hline half dose & 11.02 & 29.82 & 59.95 & 33.60 & 12.32 & 36.75 & 65.00 & 38.02 \\
\hline half + my & 13.88 & 38.00 & 65.87 & 39.25 & 13.87 & 41.69 & 73.57 & 43.04 \\
\hline half $+\mathrm{mi}$ & 13.00 & 36.66 & 63.00 & 37.55 & 13.00 & 40.02 & 71.00 & 41.34 \\
\hline half + TDZ & 12.29 & 35.32 & 61.25 & 36.29 & 12.55 & 38.25 & 68.10 & 39.63 \\
\hline half + my + mi & 16.88 & 47.00 & 80.66 & 48.18 & 18.81 & 49.65 & 88.00 & 52.15 \\
\hline half + my + TDZ & 15.31 & 44.25 & 74.72 & 44.76 & 16.56 & 46.00 & 82.07 & 48.21 \\
\hline half $+\mathrm{mi}+\mathrm{TDZ}$ & 14.00 & 41.08 & 72.22 & 42.43 & 15.00 & 45.21 & 76.69 & 45.63 \\
\hline Mean & 18.17 & 52.80 & 91.71 & & 19.88 & 57.06 & 101.47 & \\
\hline L.S.D.0.05 & $A=6.73$ & $B=3.01$ & $\mathrm{AB}=11.66$ & & $A=7.34$ & $B=3.60$ & $\mathrm{AB}=12.32$ & \\
\hline
\end{tabular}

Table 7. Effect of chemical fertilization, biofertilizer and TDZ on mean fresh weight of roots (g/plant) of anise plant during 2012/2013 and 2013/2014 seasons.

\begin{tabular}{|c|c|c|c|c|c|c|c|c|}
\hline \multirow{4}{*}{ Treatment (A) } & \multicolumn{8}{|c|}{ Growing season } \\
\hline & \multicolumn{4}{|c|}{$2012-2013$} & \multicolumn{4}{|c|}{ 2013-2014 } \\
\hline & \multicolumn{8}{|c|}{ Sampling data (month) (B) } \\
\hline & 2 & 4 & 6 & Mean & 2 & 4 & 6 & Mean \\
\hline Zero & 1.23 & 2.75 & 4.55 & 2.84 & 1.29 & 3.00 & 5.85 & 3.38 \\
\hline full dose & 2.50 & 5.01 & 7.50 & 5.00 & 3.00 & 6.02 & 8.77 & 5.93 \\
\hline full + my & 2.77 & 6.00 & 8.55 & 5.77 & 2.82 & 7.07 & 9.69 & 6.53 \\
\hline full + mi & 2.60 & 6.03 & 8.33 & 5.65 & 3.21 & 7.00 & 9.25 & 6.49 \\
\hline full + TDZ & 2.58 & 5.44 & 5.87 & 4.63 & 3.10 & 6.73 & 8.90 & 6.24 \\
\hline full + my + mi & 3.26 & 6.78 & 9.80 & 6.61 & 3.70 & 7.50 & 10.81 & 7.34 \\
\hline full + my + TDZ & 3.10 & 6.50 & 9.70 & 6.43 & 3.58 & 7.21 & 10.22 & 7.00 \\
\hline full + mi + TDZ & 3.08 & 6.29 & 9.56 & 6.31 & 3.50 & 7.15 & 10.00 & 6.88 \\
\hline half dose & 1.40 & 3.40 & 5.00 & 3.27 & 1.95 & 3.90 & 6.00 & 3.95 \\
\hline half + my & 1.80 & 4.00 & 6.49 & 4.10 & 2.14 & 4.42 & 6.75 & 4.44 \\
\hline half + mi & 1.69 & 3.91 & 6.00 & 3.87 & 2.07 & 4.30 & 6.58 & 4.32 \\
\hline half + TDZ & 1.50 & 3.59 & 5.20 & 3.43 & 2.00 & 4.18 & 6.25 & 4.14 \\
\hline half + my + mi & 2.00 & 4.70 & 6.90 & 4.53 & 2.50 & 4.75 & 7.20 & 4.82 \\
\hline half + my + TDZ & 1.97 & 4.67 & 6.75 & 4.46 & 2.28 & 4.60 & 7.02 & 4.63 \\
\hline half + mi + TDZ & 1.85 & 4.42 & 6.70 & 4.32 & 2.20 & 4.58 & 7.00 & 4.59 \\
\hline Mean & 2.22 & 4.90 & 7.13 & & 2.62 & 5.49 & 8.02 & \\
\hline L.S.D.0.05 & $A=0.97$ & $\mathrm{~B}=0.43$ & $\mathrm{AB}=1.67$ & & $\mathrm{~A}=1.11$ & $\mathrm{~B}=0.55$ & $\mathrm{AB}=1.90$ & \\
\hline
\end{tabular}


Table 8. Effect of chemical fertilization, biofertilizer and TDZ on mean dry weight of shoots (g/plant) of anise plant during 2012/2013 and 2013/2014 seasons.

\begin{tabular}{|c|c|c|c|c|c|c|c|c|}
\hline \multirow{4}{*}{ Treatment (A) } & \multicolumn{8}{|c|}{ Growing season } \\
\hline & \multicolumn{4}{|c|}{$2012-2013$} & \multicolumn{4}{|c|}{ 2013-2014 } \\
\hline & \multicolumn{8}{|c|}{ Sampling data (month) (B) } \\
\hline & 2 & 4 & 6 & Mean & 2 & 4 & 6 & Mean \\
\hline Zero & 0.83 & 3.93 & 8.25 & 4.34 & 0.89 & 4.25 & 8.72 & 4.62 \\
\hline full dose & 3.00 & 9.00 & 16.00 & 9.33 & 4.35 & 11.80 & 21.00 & 12.38 \\
\hline full + my & 3.57 & 11.69 & 18.8 & 11.35 & 4.80 & 12.87 & 23.55 & 13.74 \\
\hline full + mi & 3.40 & 11.19 & 17.66 & 10.75 & 4.71 & 12.58 & 22.87 & 13.39 \\
\hline full + TDZ & 3.25 & 10.79 & 16.89 & 10.31 & 4.50 & 12.30 & 21.79 & 12.86 \\
\hline full + my + mi & 4.44 & 13.00 & 23.73 & 13.72 & 5.73 & 15.48 & 27.80 & 16.34 \\
\hline full + my + TDZ & 4.12 & 12.75 & 21.00 & 12.62 & 5.40 & 13.87 & 25.08 & 14.78 \\
\hline full + mi + TDZ & 3.80 & 12.00 & 20.57 & 12.12 & 5.09 & 13.03 & 24.75 & 14.29 \\
\hline half dose & 1.20 & 5.15 & 10.65 & 5.67 & 2.50 & 6.62 & 11.80 & 6.97 \\
\hline half + my & 1.44 & 5.99 & 12.00 & 6.48 & 2.85 & 7.45 & 13.69 & 8.00 \\
\hline half + mi & 1.39 & 5.68 & 11.67 & 6.25 & 2.70 & 7.18 & 13.80 & 7.89 \\
\hline half + TDZ & 1.39 & 5.55 & 11.01 & 5.98 & 2.61 & 6.92 & 12.15 & 7.23 \\
\hline half $+m y+m i$ & 2.24 & 7.12 & 13.50 & 7.62 & 3.40 & 9.00 & 15.90 & 9.43 \\
\hline half $+\mathrm{my}+\mathrm{TDZ}$ & 2.08 & 6.95 & 13.37 & 7.47 & 3.19 & 8.20 & 14.57 & 8.65 \\
\hline half $+\mathrm{mi}+\mathrm{TDZ}$ & 1.98 & 6.54 & 13.00 & 7.17 & 3.00 & 7.75 & 14.07 & 8.27 \\
\hline Mean & 2.54 & 8.49 & 15.21 & & 3.71 & 9.95 & 18.10 & \\
\hline L.S.D.0.05 & 2.21 & $=0.99$ & $3=3.83$ & & $=2.7$ & $\mathrm{~B}=1.3$ & $\mathrm{AB}=4.30$ & \\
\hline
\end{tabular}


Table 9. Effect of chemical fertilization, biofertilizer and TDZ on mean dry weight of roots (g/plant) of anise plant during 2012/2013 and 2013/2014 seasons.

\begin{tabular}{|c|c|c|c|c|c|c|c|c|}
\hline \multirow{4}{*}{ Treatment (A) } & \multicolumn{8}{|c|}{ Growing season } \\
\hline & \multicolumn{4}{|c|}{$2012-2013$} & \multicolumn{4}{|c|}{$2013-2014$} \\
\hline & \multicolumn{8}{|c|}{ Sampling data (month) (B) } \\
\hline & 2 & 4 & 6 & Mean & 2 & 4 & 6 & Mean \\
\hline zero & 0.22 & 0.44 & 0.80 & 0.49 & 0.27 & 0.50 & 0.91 & 0.56 \\
\hline full dose & 0.40 & 0.80 & 1.40 & 0.87 & 0.52 & 1.32 & 1.90 & 1.25 \\
\hline full + my & 0.47 & 0.92 & 1.73 & 1.04 & 0.56 & 1.43 & 2.04 & 1.34 \\
\hline full + mi & 0.44 & 0.89 & 1.72 & 1.02 & 0.55 & 1.39 & 2.00 & 1.31 \\
\hline full + TDZ & 0.41 & 0.84 & 1.68 & 0.98 & 0.53 & 1.36 & 1.97 & 1.29 \\
\hline full + my + mi & 0.55 & 1.13 & 1.95 & 1.21 & 0.63 & 1.55 & 2.29 & 1.49 \\
\hline full + my + TDZ & 0.52 & 1.08 & 1.90 & 1.17 & 0.60 & 1.48 & 2.14 & 1.41 \\
\hline full + mi + TDZ & 0.49 & 1.01 & 1.87 & 1.12 & 0.58 & 1.45 & 2.10 & 1.38 \\
\hline half dose & 0.26 & 0.51 & 1.00 & 0.59 & 0.32 & 0.87 & 1.58 & 0.92 \\
\hline half + my & 0.29 & 0.63 & 1.15 & 0.69 & 0.36 & 0.94 & 1.68 & 0.99 \\
\hline half + mi & 0.28 & 0.62 & 1.03 & 0.64 & 0.35 & 0.91 & 1.65 & 0.97 \\
\hline half + TDZ & 0.28 & 0.55 & 1.02 & 0.62 & 0.33 & 0.89 & 1.60 & 0.94 \\
\hline half + my + mi & 0.35 & 0.73 & 1.20 & 0.76 & 0.41 & 1.05 & 1.79 & 1.08 \\
\hline half + my + TDZ & 0.32 & 0.71 & 1.19 & 0.74 & 0.39 & 1.00 & 1.77 & 1.05 \\
\hline half $+\mathrm{mi}+\mathrm{TDZ}$ & 0.31 & 0.68 & 1.00 & 0.66 & 0.38 & 0.97 & 1.74 & 1.03 \\
\hline Mean & 0.37 & 0.77 & 1.38 & & 0.45 & 1.14 & 1.81 & \\
\hline L.S.D.0.05 & $A=0.29$ & $\mathrm{~B}=0.13$ & $B=0.51$ & & $A=0.33$ & $\mathrm{~B}=0.15$ & $B=0.57$ & \\
\hline
\end{tabular}


Table 10. Effect of chemical fertilization, biofertilizer and TDZ on mean plant height $(\mathrm{cm})$ of anise plant during 2012/2013 and 2013/2014 seasons.

\begin{tabular}{|c|c|c|c|c|c|c|c|c|}
\hline \multirow{4}{*}{ Treatment (A) } & \multicolumn{8}{|c|}{ Growing season } \\
\hline & \multicolumn{4}{|c|}{$2012-2013$} & \multicolumn{4}{|c|}{ 2013-2014 } \\
\hline & \multicolumn{8}{|c|}{ Sampling data (month) (B) } \\
\hline & 2 & 4 & 6 & Mean & 2 & 4 & 6 & Mean \\
\hline Zero & 10.00 & 18.80 & 30.57 & 19.79 & 12.25 & 20.11 & 33.52 & 21.96 \\
\hline full dose & 23.71 & 43.95 & 58.00 & 41.89 & 26.00 & 49.55 & 66.90 & 47.48 \\
\hline full + my & 26.91 & 49.67 & 72.22 & 49.60 & 28.00 & 55.00 & 74.43 & 52.48 \\
\hline full + mi & 24.25 & 48.20 & 71.00 & 47.82 & 27.05 & 53.52 & 71.00 & 50.52 \\
\hline full + TDZ & 23.00 & 45.77 & 65.00 & 44.59 & 26.82 & 51.00 & 68.87 & 48.90 \\
\hline full $+\mathrm{my}+\mathrm{mi}$ & 30.27 & 58.25 & 80.22 & 56.25 & 34.52 & 65.00 & 88.20 & 62.57 \\
\hline full + my + TDZ & 29.30 & 54.65 & 80.00 & 54.65 & 31.35 & 60.28 & 82.57 & 58.07 \\
\hline full + mi + TDZ & 28.00 & 52.00 & 77.57 & 52.52 & 28.95 & 57.75 & 78.82 & 55.17 \\
\hline half dose & 12.00 & 25.97 & 39.29 & 25.75 & 15.56 & 28.47 & 38.29 & 27.44 \\
\hline half + my & 14.05 & 29.35 & 44.00 & 29.13 & 17.00 & 31.07 & 44.00 & 30.69 \\
\hline half + mi & 14.00 & 28.80 & 43.72 & 28.84 & 16.34 & 30.60 & 42.89 & 29.94 \\
\hline half + TDZ & 12.95 & 26.21 & 40.00 & 26.39 & 15.92 & 29.50 & 40.02 & 28.48 \\
\hline half $+m y+m i$ & 17.00 & 35.96 & 50.21 & 34.39 & 19.57 & 36.89 & 51.52 & 35.99 \\
\hline half + my + TDZ & 16.66 & 34.00 & 48.88 & 33.18 & 18.22 & 35.53 & 48.88 & 34.21 \\
\hline half + mi + TDZ & 15.25 & 32.65 & 47.08 & 31.66 & 17.50 & 32.88 & 45.75 & 32.04 \\
\hline Mean & 19.82 & 38.95 & 56.52 & & 22.34 & 42.48 & 58.38 & \\
\hline
\end{tabular}

Table 11. Effect of chemical fertilization, biofertilizer and TDZ on mean umbel number/plant of anise plant during 2012/2013 and 2013/2014 seasons.

\begin{tabular}{llll}
\hline \multirow{2}{*}{ Treatment } & \multicolumn{2}{l}{ Growing season } & \\
\cline { 2 - 4 } & $2012-2013$ & $2013-2014$ & Mean \\
\hline Zero & 20.43 & 25.49 & 22.96 \\
full dose & 79.65 & 90.00 & 84.825 \\
full + my & 98.07 & 101.00 & 99.535 \\
full + mi & 95.75 & 98.78 & 97.265 \\
full + TDZ & 86.95 & 95.50 & 91.225 \\
full + my + mi & 113.63 & 118.43 & 116.03 \\
full + my + TDZ & 105.63 & 110.91 & 108.27 \\
full + mi + TDZ & 100.00 & 105.08 & 102.54 \\
half dose & 45.37 & 51.77 & 48.57 \\
half + my & 52.89 & 59.83 & 56.36 \\
half + mi & 50.93 & 56.00 & 53.465
\end{tabular}




\begin{tabular}{|c|c|c|c|}
\hline half + TDZ & 47.04 & 54.44 & 50.74 \\
\hline half + my + mi & 60.88 & 70.90 & 65.89 \\
\hline half + my + TDZ & 60.67 & 65.12 & 62.895 \\
\hline half + mi + TDZ & 56 & 61.66 & 58.83 \\
\hline Mean & 71.59 & 77.66 & \\
\hline $\begin{array}{l}\text { L.S.D.0.05 } \\
\text { Table 12. Effect o } \\
\text { during } 2012 / 2013\end{array}$ & $\begin{array}{l}7.55 \\
\text { iofertilizer an }\end{array}$ & $\begin{array}{l}8.60 \\
\text { nean weight }\end{array}$ & plant) of \\
\hline \multirow{2}{*}{ Treatment } & \multicolumn{3}{|c|}{ Growing season } \\
\hline & 2012-2013 & 2013-2014 & Mean \\
\hline Zero & 11.5 & 13.22 & 12.36 \\
\hline full dose & 35.27 & 37.00 & 36.14 \\
\hline full + my & 39.00 & 41.92 & 40.46 \\
\hline full + mi & 37.92 & 39.15 & 38.54 \\
\hline full + TDZ & 36.07 & 37.58 & 36.83 \\
\hline full + my + mi & 48.72 & 49.82 & 49.27 \\
\hline full + my + TDZ & 44.45 & 46.00 & 45.23 \\
\hline full + mi + TDZ & 42.77 & 44.35 & 43.56 \\
\hline half dose & 18.25 & 20.17 & 19.21 \\
\hline half + my & 24.25 & 24.98 & 24.62 \\
\hline half + mi & 22.96 & 23.00 & 22.98 \\
\hline half + TDZ & 20.00 & 21.87 & 20.94 \\
\hline half + my + mi & 27.87 & 30.08 & 28.98 \\
\hline half + my + TDZ & 26.00 & 27.89 & 26.95 \\
\hline half $+\mathrm{mi}+\mathrm{TDZ}$ & 24.80 & 26.93 & 25.87 \\
\hline Mean & 30.66 & 32.26 & \\
\hline L.S.D.0.05 & 6.27 & 6.97 & \\
\hline
\end{tabular}

Table 13. Effect of chemical fertilization, biofertilizer and TDZ on mean chlorophyll (a) content (mg/g F.W.) of anise plant during 2012/2013 and 2013/2014 seasons.

\begin{tabular}{|c|c|c|c|c|c|c|c|c|}
\hline \multirow{4}{*}{ Treatment (A) } & \multicolumn{8}{|c|}{ Growing season } \\
\hline & \multicolumn{4}{|c|}{$2012-2013$} & \multicolumn{4}{|c|}{ 2013-2014 } \\
\hline & \multicolumn{8}{|c|}{ Sampling data (month) (B) } \\
\hline & 2 & 4 & 6 & Mean & 2 & 4 & 6 & Mean \\
\hline Zero & 0.20 & 0.39 & 0.50 & 0.36 & 0.24 & 0.45 & 0.61 & 0.43 \\
\hline full dose & 0.55 & 0.95 & 1.35 & 0.95 & 0.65 & 1.17 & 1.50 & 1.11 \\
\hline full + my & 0.70 & 1.26 & 1.69 & 1.22 & 0.75 & 1.42 & 1.83 & 1.33 \\
\hline full + mi & 0.62 & 1.08 & 1.49 & 1.06 & 0.70 & 1.35 & 1.69 & 1.25 \\
\hline full + TDZ & 0.59 & 0.98 & 1.40 & 0.99 & 0.67 & 1.20 & 1.55 & 1.14 \\
\hline full + my + mi & 0.74 & 1.31 & 1.85 & 1.30 & 0.87 & 1.56 & 2.03 & 1.49 \\
\hline full + my + TDZ & 0.72 & 1.26 & 1.74 & 1.24 & 0.80 & 1.44 & 1.09 & 1.11 \\
\hline full + mi + TDZ & 0.65 & 1.19 & 1.52 & 1.12 & 0.71 & 1.39 & 1.72 & 1.27 \\
\hline half dose & 0.30 & 0.53 & 0.77 & 0.53 & 0.36 & 0.60 & 0.85 & 0.60 \\
\hline half + my & 0.41 & 0.68 & 0.90 & 0.66 & 0.44 & 0.75 & 0.98 & 0.72 \\
\hline half $+\mathrm{mi}$ & 0.35 & 0.62 & 0.82 & 0.60 & 0.40 & 0.67 & 0.92 & 0.66 \\
\hline half + TDZ & 0.33 & 0.58 & 0.79 & 0.57 & 0.38 & 0.63 & 0.89 & 0.63 \\
\hline half + my + mi & 0.43 & 0.74 & 1.00 & 0.72 & 0.50 & 0.80 & 1.15 & 0.82 \\
\hline half + my + TDZ & 0.41 & 0.70 & 0.94 & 0.68 & 0.44 & 0.77 & 1.00 & 0.74 \\
\hline half + mi + TDZ & 0.38 & 0.63 & 0.85 & 0.62 & 0.40 & 0.69 & 0.94 & 0.68 \\
\hline
\end{tabular}




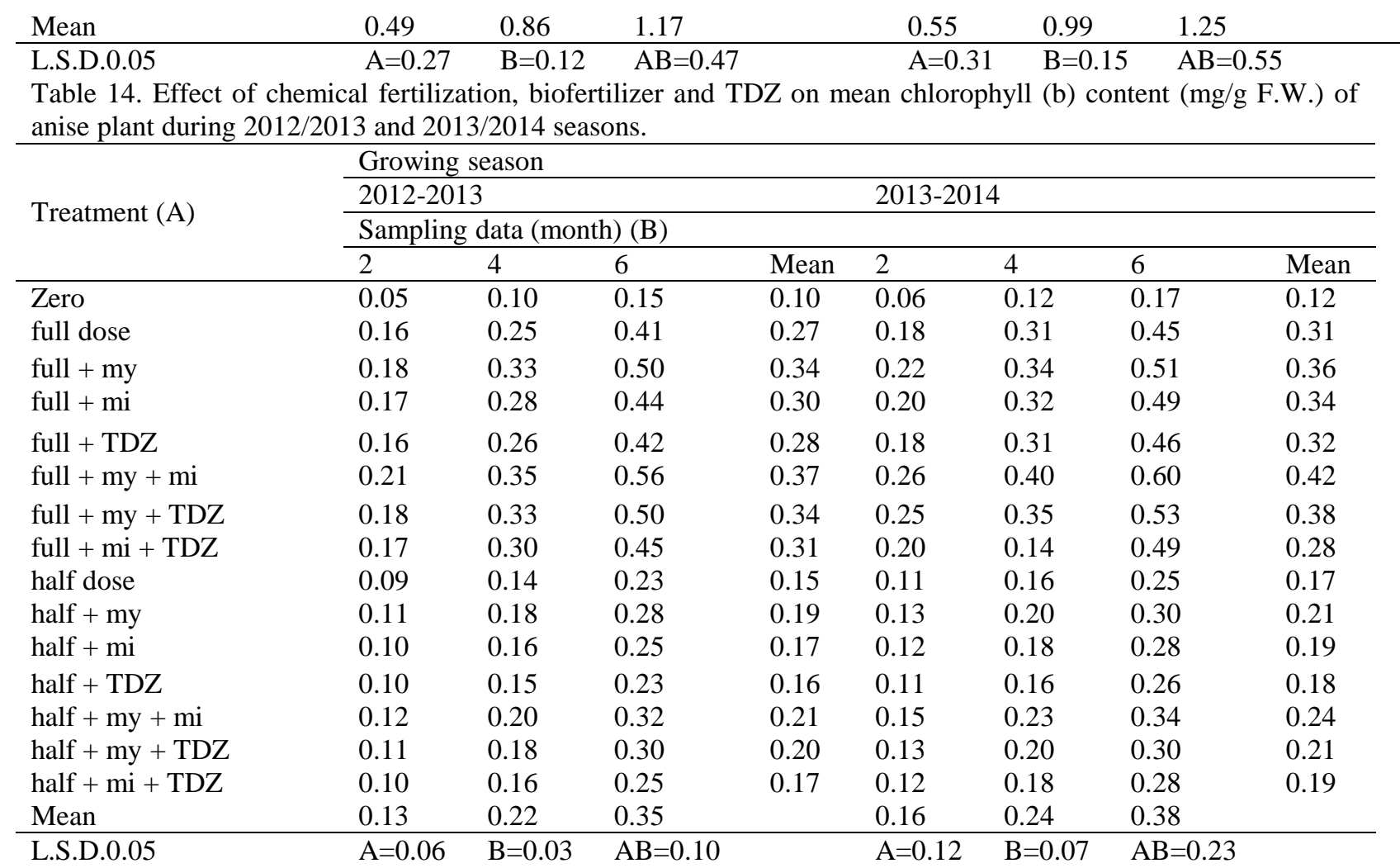

Table 15. Effect of chemical fertilization, biofertilizer and TDZ on mean caratenoides content (mg/g F.W.) of anise plant during 2012/2013 and 2013/2014 seasons.

\begin{tabular}{|c|c|c|c|c|c|c|c|c|}
\hline \multirow{4}{*}{ Treatment (A) } & \multicolumn{8}{|c|}{ Growing season } \\
\hline & $2012-20$ & & & & $2013-20$ & & & \\
\hline & \multicolumn{8}{|c|}{ Sampling data (month) (B) } \\
\hline & 2 & 4 & 6 & Mean & 2 & 4 & 6 & Mean \\
\hline Zero & 0.15 & 0.21 & 0.32 & 0.23 & 0.19 & 0.25 & 0.36 & 0.27 \\
\hline full dose & 0.40 & 0.53 & 0.74 & 0.56 & 0.43 & 0.60 & 0.88 & 0.64 \\
\hline full + my & 0.48 & 0.66 & 0.91 & 0.68 & 0.50 & 0.75 & 1.00 & 0.75 \\
\hline full + mi & 0.45 & 0.58 & 0.81 & 0.61 & 0.47 & 0.70 & 0.93 & 0.70 \\
\hline full + TDZ & 0.42 & 0.55 & 0.76 & 0.58 & 0.44 & 0.65 & 0.90 & 0.66 \\
\hline full + my + mi & 0.53 & 0.72 & 1.00 & 0.75 & 0.59 & 0.83 & 1.17 & 0.86 \\
\hline full + my + TDZ & 0.49 & 0.69 & 0.95 & 0.71 & 0.53 & 0.77 & 1.05 & 0.78 \\
\hline full + mi + TDZ & 0.45 & 0.60 & 0.83 & 0.63 & 0.48 & 0.71 & 0.94 & 0.71 \\
\hline half dose & 0.23 & 0.30 & 0.40 & 0.31 & 0.24 & 0.35 & 0.46 & 0.35 \\
\hline half + my & 0.27 & 0.38 & 0.50 & 0.38 & 0.30 & 0.41 & 0.59 & 0.43 \\
\hline half + mi & 0.25 & 0.34 & 0.47 & 0.35 & 0.27 & 0.38 & 0.53 & 0.39 \\
\hline half + TDZ & 0.23 & 0.32 & 0.43 & 0.33 & 0.25 & 0.36 & 0.49 & 0.37 \\
\hline half + my + mi & 0.30 & 0.40 & 0.56 & 0.42 & 0.33 & 0.47 & 0.66 & 0.49 \\
\hline half + my + TDZ & 0.29 & 0.38 & 0.50 & 0.39 & 0.31 & 0.42 & 0.60 & 0.44 \\
\hline half + mi + TDZ & 0.27 & 0.35 & 0.48 & 0.37 & 0.28 & 0.38 & 0.54 & 0.40 \\
\hline Mean & 0.35 & 0.47 & 0.64 & & 0.37 & 0.54 & 0.74 & \\
\hline L.S.D.0.05 & $\mathrm{A}=0.11$ & $\mathrm{~B}=0.05$ & $\mathrm{AB}=0.18$ & & $\mathrm{~A}=0.16$ & $\mathrm{~B}=0.10$ & $\mathrm{AB}=0$ & \\
\hline
\end{tabular}

Table 16. Effect of chemical fertilization, biofertilizer and TDZ on mean nitrogen $\%$ in dry shoots of anise plant during 2012/2013 and 2013/2014 seasons.

\begin{tabular}{|c|c|c|c|c|c|c|c|}
\hline \multirow{4}{*}{ Treatment $(\mathrm{A})$} & \multicolumn{7}{|l|}{ Growing season } \\
\hline & \multicolumn{3}{|l|}{$2012-2013$} & \multicolumn{4}{|c|}{ 2013-2014 } \\
\hline & \multicolumn{7}{|c|}{ Sampling data (month) (B) } \\
\hline & $2 \quad 4$ & 6 & Mean & 2 & 4 & 6 & Mean \\
\hline Zero & 0.75 & 1.13 & 0.93 & 0.80 & 1.00 & 1.18 & 0.99 \\
\hline
\end{tabular}




\begin{tabular}{lllllllll} 
full dose & 1.60 & 2.25 & 2.80 & 2.22 & 1.50 & 2.50 & 3.00 & 2.33 \\
full + my & 1.80 & 2.5 & 3.3 & 2.53 & 1.95 & 2.77 & 3.40 & 2.71 \\
full + mi & 1.75 & 2.32 & 3.17 & 2.41 & 1.90 & 2.61 & 3.25 & 2.59 \\
full + TDZ & 1.64 & 2.27 & 3.00 & 2.30 & 1.90 & 2.58 & 3.18 & 2.55 \\
full + my + mi & 2.20 & 3.00 & 3.70 & 2.97 & 2.50 & 3.35 & 3.98 & 3.28 \\
full + my + TDZ & 2.00 & 2.71 & 3.45 & 2.72 & 2.30 & 3.00 & 3.70 & 3.00 \\
full + mi + TDZ & 1.92 & 2.50 & 3.35 & 2.59 & 2.00 & 2.81 & 3.58 & 2.80 \\
half dose & 0.93 & 1.35 & 1.60 & 1.29 & 1.00 & 1.42 & 1.70 & 1.37 \\
half + my & 1.02 & 1.40 & 1.76 & 1.39 & 1.10 & 1.65 & 1.82 & 1.52 \\
half + mi & 1.02 & 1.39 & 1.74 & 1.38 & 1.05 & 1.60 & 1.77 & 1.47 \\
half + TDZ & 0.98 & 1.37 & 1.68 & 1.34 & 1.00 & 1.57 & 1.75 & 1.44 \\
half + my + mi & 1.20 & 1.67 & 2.10 & 1.66 & 1.20 & 1.50 & 2.23 & 1.64 \\
half + my + TDZ & 1.17 & 1.50 & 2.00 & 1.56 & 1.15 & 1.78 & 2.00 & 1.64 \\
half + mi + TDZ & 1.08 & 1.44 & 1.85 & 1.46 & 1.10 & 1.70 & 1.90 & 1.57 \\
Mean & 1.40 & 1.90 & 2.44 & & 1.50 & 2.12 & 2.56 & \\
\hline L.S.D.0.05 & $\mathrm{A}=0.27$ & $\mathrm{~B}=0.12$ & $\mathrm{AB}=0.46$ & & $\mathrm{~A}=0.30$ & $\mathrm{~B}=0.16$ & $\mathrm{AB}=0.54$ &
\end{tabular}

Table 17. Effect of chemical fertilization, biofertilizer and TDZ on mean phosphorus \% in dry shoots of anise plant during 2012/2013 and 2013/2014 seasons.

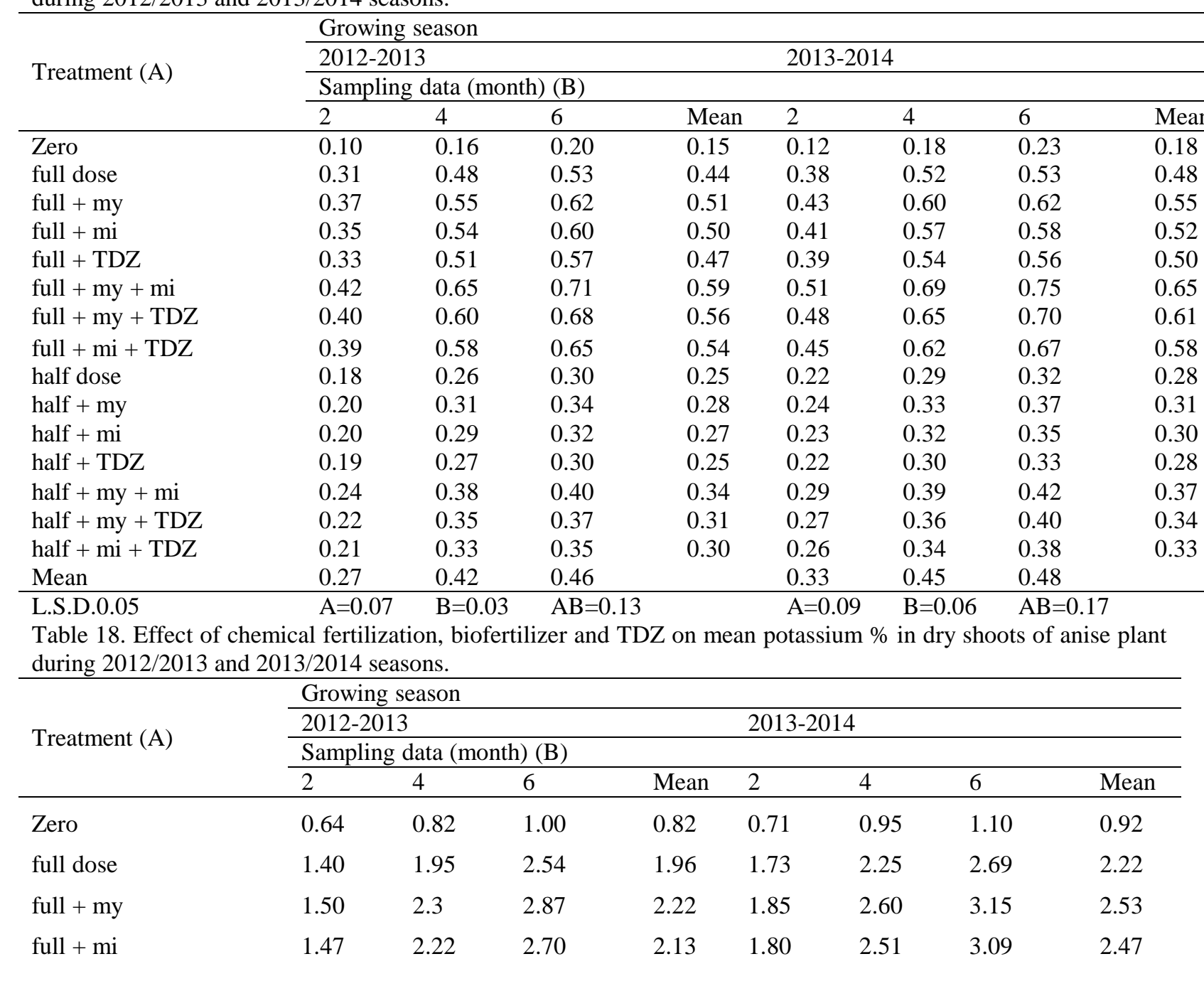




\begin{tabular}{|c|c|c|c|c|c|c|c|c|}
\hline full + TDZ & 1.42 & 2.00 & 2.59 & 2.00 & 1.77 & 2.30 & 2.80 & 2.29 \\
\hline full $+m y+m i$ & 1.90 & 2.60 & 3.39 & 2.63 & 2.23 & 3.00 & 3.59 & 2.94 \\
\hline full + my + TDZ & 1.70 & 2.42 & 3.10 & 2.41 & 2.20 & 2.80 & 3.33 & 2.78 \\
\hline full + mi + TDZ & 1.58 & 2.35 & 3.00 & 2.31 & 1.91 & 2.72 & 3.28 & 2.64 \\
\hline half dose & 0.80 & 1.10 & 1.43 & 1.11 & 0.97 & 1.27 & 1.51 & 1.25 \\
\hline half + my & 0.85 & 1.28 & 1.63 & 1.25 & 1.05 & 1.40 & 1.65 & 1.37 \\
\hline half + mi & 0.83 & 1.20 & 1.56 & 1.20 & 1.00 & 1.35 & 1.60 & 1.32 \\
\hline half + TDZ & 0.80 & 1.18 & 1.49 & 1.16 & 1.00 & 1.30 & 1.57 & 1.29 \\
\hline half + my + mi & 1.09 & 1.46 & 1.91 & 1.49 & 1.29 & 1.69 & 2.00 & 1.66 \\
\hline half + my + TDZ & 0.92 & 1.37 & 1.75 & 1.35 & 1.10 & 1.52 & 1.88 & 1.50 \\
\hline half + mi + TDZ & 0.88 & 1.30 & 1.70 & 1.29 & 1.09 & 1.42 & 1.72 & 1.41 \\
\hline Mean & 1.19 & 1.70 & 2.18 & & 1.45 & 1.94 & 2.33 & \\
\hline $\begin{array}{l}\text { L.S.D.0.05 } \\
\text { Table 19. Effect o } \\
\text { during } 2012 / 2013\end{array}$ & $\begin{array}{l}\mathrm{A}=0.52 \\
\text { cal fertili } \\
3 / 2014 \mathrm{se}\end{array}$ & $\begin{array}{l}\mathrm{B}=0.23 \\
\text { tion, biof } \\
\text { ons. }\end{array}$ & $\begin{array}{l}\mathrm{AB}=0.90 \\
\text { ilizer and }\end{array}$ & 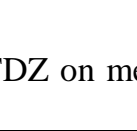 & $\begin{array}{l}\mathrm{A}=0.69 \\
\text { ean carbol }\end{array}$ & $\begin{array}{l}3=0.33 \\
\text { rates \% ir }\end{array}$ & $\begin{array}{c}\mathrm{AB}=1.29 \\
\mathrm{n} \text { dry shoot }\end{array}$ & lant \\
\hline \multirow{4}{*}{ Treatment (A) } & \multicolumn{8}{|c|}{ Growing season } \\
\hline & $2012-201$ & & & & $2013-20$ & 14 & & \\
\hline & \multicolumn{8}{|c|}{ Sampling data (month) (B) } \\
\hline & 2 & 4 & 6 & Mean & 2 & 4 & 6 & Mean \\
\hline Zero & 22.00 & 24.00 & 27.00 & 24.33 & 23.00 & 26.00 & 28.00 & 25.67 \\
\hline full dose & 34.00 & 40.00 & 44.00 & 39.33 & 36.00 & 42.00 & 45.00 & 41.00 \\
\hline full + my & 36.00 & 44.00 & 49.00 & 43.00 & 40.00 & 48.00 & 49.00 & 45.67 \\
\hline full + mi & 35.00 & 43.00 & 48.00 & 42.00 & 39.00 & 47.00 & 47.00 & 44.33 \\
\hline full + TDZ & 34.00 & 41.00 & 46.00 & 40.33 & 38.00 & 46.00 & 46.00 & 43.33 \\
\hline full $+m y+m i$ & 42.00 & 49.00 & 56.00 & 49.00 & 45.00 & 53.00 & 58.00 & 52.00 \\
\hline full + my + TDZ & 40.00 & 47.00 & 52.00 & 46.33 & 43.00 & 51.00 & 54.00 & 49.33 \\
\hline full + mi + TDZ & 38.00 & 46.00 & 51.00 & 45.00 & 42.00 & 50.00 & 52.00 & 48.00 \\
\hline half dose & 24.00 & 28.00 & 30.00 & 27.33 & 27.00 & 30.00 & 31.00 & 29.33 \\
\hline half + my & 26.00 & 30.00 & 33.00 & 29.67 & 29.00 & 31.00 & 33.00 & 31.00 \\
\hline half + mi & 25.00 & 29.00 & 31.00 & 28.33 & 28.00 & 31.00 & 33.00 & 30.67 \\
\hline half + TDZ & 25.00 & 28.00 & 30.00 & 27.67 & 28.00 & 30.00 & 32.00 & 30.00 \\
\hline half $+\mathrm{my}+\mathrm{mi}$ & 28.00 & 34.00 & 36.00 & 32.67 & 32.00 & 35.00 & 38.00 & 35.00 \\
\hline half + my + TDZ & 27.00 & 33.00 & 35.00 & 31.67 & 31.00 & 33.00 & 37.00 & 33.67 \\
\hline half + mi + TDZ & 26.00 & 31.00 & 34.00 & 30.33 & 30.00 & 32.00 & 35.00 & 32.33 \\
\hline Mean & 30.80 & 36.47 & 40.13 & & 34.07 & 39.00 & 41.20 & \\
\hline L.S.D.0.05 & $\mathrm{A}=7.39$ & $\mathrm{~B}=3.30$ & $\mathrm{AB}=12.79$ & & $\mathrm{~A}=8.45$ & $B=4.02$ & $\mathrm{AB}=1$ & \\
\hline
\end{tabular}

Table 20. Effect of chemical fertilization, biofertilizer and TDZ on mean protein $\%$ in dry shoots of anise plant during 2012/2013 and 2013/2014 seasons.

\begin{tabular}{|c|c|c|c|c|c|c|c|c|}
\hline \multirow{4}{*}{ Treatment (A) } & \multicolumn{8}{|c|}{ Growing season } \\
\hline & $2012-$ & & & & $2013-$ & & & \\
\hline & \multicolumn{8}{|c|}{ Sampling data (month) (B) } \\
\hline & 2 & 4 & 6 & Mean & 2 & 4 & 6 & Mean \\
\hline Zero & 4.69 & 5.63 & 7.06 & 5.79 & 5.00 & 6.25 & 7.38 & 6.21 \\
\hline full dose & 10.00 & 14.06 & 17.50 & 13.85 & 11.88 & 15.62 & 18.75 & 15.42 \\
\hline full + my & 11.25 & 15.62 & 20.63 & 15.83 & 12.50 & 17.31 & 21.25 & 17.02 \\
\hline full $+\mathrm{mi}$ & 10.94 & 14.50 & 19.81 & 15.08 & 12.19 & 16.31 & 20.31 & 16.27 \\
\hline full + TDZ & 10.25 & 14.19 & 18.75 & 14.40 & 11.88 & 16.13 & 19.88 & 15.96 \\
\hline full + my + mi & 13.75 & 18.75 & 23.13 & 18.54 & 15.63 & 20.94 & 24.88 & 20.48 \\
\hline full + my + TDZ & 12.50 & 16.94 & 21.56 & 17.00 & 14.38 & 18.75 & 23.13 & 18.75 \\
\hline full + mi + TDZ & 12.00 & 15.62 & 20.94 & 16.19 & 12.50 & 17.56 & 22.38 & 17.48 \\
\hline half dose & 5.81 & 8.44 & 10.00 & 8.08 & 6.25 & 8.88 & 10.63 & 8.59 \\
\hline
\end{tabular}




\begin{tabular}{lllllllll} 
half + my & 6.38 & 8.75 & 11.00 & 8.71 & 6.88 & 10.31 & 11.38 & 9.52 \\
half + mi & 6.38 & 8.69 & 10.88 & 8.65 & 6.88 & 10.00 & 11.06 & 9.31 \\
half + TDZ & 6.13 & 8.56 & 10.50 & 8.40 & 6.56 & 9.81 & 10.94 & 9.10 \\
half + my + mi & 7.50 & 10.44 & 13.13 & 10.36 & 9.38 & 11.88 & 13.94 & 11.73 \\
half + my + TDZ & 7.31 & 9.38 & 12.50 & 9.73 & 7.50 & 11.13 & 12.50 & 10.38 \\
half + mi + TDZ & 6.75 & 9.00 & 11.56 & 9.10 & 7.19 & 11.13 & 11.88 & 10.07 \\
Mean & 8.78 & 11.90 & 15.26 & & 9.77 & 13.47 & 16.02 & \\
\hline L.S.D.0.05 & $\mathrm{A}=2.36$ & $\mathrm{~B}=1.06$ & $\mathrm{AB}=4.10$ & & $\mathrm{~A}=3.50$ & $\mathrm{~B}=1.52$ & $\mathrm{AB}=5.57$
\end{tabular}

\section{REFERENCES}

Agamy, R.A.; Mohamed, G.F. and Rady, M.M. (2012). Influence of the Application of Fertilizer type on Growth, yield, anatomical structure and some shemical somponents of Wheat (Triticum aestivum L.) Grown in Newly Reclaimed Soil. Australian Journal of Basic and Applied Sciences, 6(3): 561-570.

Al-Haddad, Z. K. ; Soliman, A. Sh.; Morsy, E.M.; Kamel S.M. and El Sayed, A.A.(2014). Effect of Different Bio Fertilizers and Soil Media on Growth and Chemical Composition of Eucalyptus camaldulensis in North Africa. Journal of Horticultural Science \& Ornamental Plants 6 (2): 5970.

Al-Khiat S. and Ali, H. (2006). Effect of Cyanobacteria as a Soil Conditioner and Biofertilizer on Growth and Some Biochemical Characteristics of Tomato (Lycopersicon esculentum L.) Seedlings. Thesis Submitted in partial fulfillment of the requirements of the Degree of Master of Science (M. Sc.) Microbiology (Algae), King Saud University. Special Publication, 6, p: 1-4.

Amal, A.; Wedad, E.; Heggo, A.M. and Enas A. H. (2014). Effect of dual inoculation with arbuscular mycorrhizal fungi and sulphur-oxidising bacteria on onion (Allium cepa L.) and maize (Zea mays L.) grown in sandy soil under green house conditions. Annals of Agricultural Sciences Volume 59, Issue 1, June 2014, Pages 109-118.

Arnon, D.I. (1949). Copper enzymes in isolated chloroplasts. Polyphenol oxidase in Beta vulgaris. Plant Physiol 24: 1-15

Association of Officinal Agricultural chemists (AOAC) (1960). Officinal methods of analysis $9^{\text {th }}$ edition, Washington D.C.

Black, C. A.; Evans, D. D.; White, J. L.; Ensmiger, L. E. and Clark, F. E. (1965). Methods of soil analysis. Part 2. Agronomy. 9, ASA, Madison, WI, 1122pp.

Chevallier, A. (1996). The Encyclopedia of Medicinal Plants. 1st Edn., DK Publishing Inc., New York, USA., pp: 259.

Contra costa, clean water program (2003). Biofertilizers and Mycorrhizae. Plant Physiol, P: 1-4.

Dubois, M.; Gilles, K.A.; Hamilton, J.K.; Rebers. P.A. and Smith, F. (1956). Anal. Chem., 26, p. 350. 
Earanna, N. and Govindan, R. (2002): Role of biofertilizers in mulberry production-A review. Indian J. Seric. 41(2):92-99.

Edyta, D.; Lidia S. P.; Anton H. and Beata S. (2015). Root Growth, Mycorrhizal Frequency and Soil Microorganisms in Strawberry as Affected by Biopreparations. Advances in Microbiology, 2015, 5, 65-73

El-Aal, M. M. and El-Rahman, H. M. (2014). Impact of PGPR and inorganic fertilization on growth and productivity of sweet ananas melon. International Journal of Agricultural Science and Research (IJASR) 2014 Vol. 4 No. 3 pp. 11-26.

El-Quesni, F.E. ; Hashish, K.H.I. ; Magda, M. ; Kandil, M. and Azza, M.(2013). Impact of some biofertilizers and compost on growth and chemical composition of Jatrophacurcus L. World Appl. Sci. J., 21 (6) (2013), pp. 927932.

Figueiredo, A.C.; Barroso, J.G.; Pedro, L.G. and Scheffer, J.J. (2008). Factors affecting secondary metabolite production in plants: volatile components and essential oils. Flavour Frag J 23: 213-226.

Fisher, R.A. 1950. Statistical method for research workers, Oliver and Boyd, Edinburg, London.

Harb, E.M.Z.; Ghallab, A.M. and Soliman, S.H.D. (2011). Effect of mycorrhizae, azotobacter and organic manure on the growth, seed yield and oil content of Nigella sativa L. plants grown under two levels of chemical fertilizers, NPK. Bull. Fac. Agric. Cairo Univ., 62: 173-182.

Hardy, R.W.; Burns, R.C. and HolstEn, R.D. (1973). Applications of the ecetyleneethylene assay for measurement of nitrogen fixation. Soil Biology \& Biochemistry 5, pp47-81.

Hegde, D.M.; Dwivedi, B.S. and Babu, S.N.S. (1999): Biofertilizers for cereal production in India- A review. Indian Journal of Agricultural Sciences. 69 (2):73-83.

Ichihashi, S.; Miyata, K.; Kato, K.; Miwa, T.; Nakazawa, Y.; Suzuki, A.; Kashima, R. and Kato, J.(2010). The effects of $\mathrm{NH}^{4} \mathrm{~N}$ and plant growth regulators on Phalaenopsis spiking and flowering. Acta Horticulturae; 2010. (878):335-345. 15 ref.

Jackson , M. L.(1956). Soil chemical analysis - advan ced course . Pub . by the Author . Dept. of Soils ,Univ . of Wis., Madi son, Wis . 991 p.

Jakab, A.; Anita. S.; Zsuzsa K. and Janos K. (2011). THE EFFECT OF ALTERNATIVE METHODS OF NUTRIENT SUPPLY ON SOME MICROBIOLOGICAL CHARACTERISTICS OF A CHERNOZEM SOIL. 
Analele Universităţii din Oradea, Fascicula Protecţia Mediului. Vol. XVII, 2011. 85:90.

Ramakrishnan, K. and Bhuvaneswari. G. (2014). Effect of Inoculation of AM Fungi and Beneficial Microorganisms on Growth and Nutrient Uptake of Eleusine coracana (L.) Gaertn. (Finger Millet). International Letters of Natural Sciences (Volume 13). 59-69

Khafaga, H.S. and Abd-EInaby, A.S., (2007). Physiological Studies on the adaptation of some wheat varieties under El-Wady El-Gedid conditions. African Crop Science Conference Proceedings. 8: 20472055.

Krishnaveni, S.; Theymoli B. and Sadasivam, S. (1984). Food Chem., 15, p. 229.

Kundu, S. ; DATTA, P.; Mishra, J.; Rashmi , K. and Ghosh, B.(2011). Influence of biofertilizer and inorganic fertilizer in pruned mango orchard cv. Amrapali. Journal of Crop and Weed 7(2): 100-103 (2011).

Lichtenthaler, H. K. and Wellburn, A. R. (1983) Determinations of total carotenoids and chlorophylls $a$ and $b$ of leaf extracts in different solvents. Biochemical Society Transactions 11: 591-592.

Murphy, J. and Riley, J. (1962). A modified single solution method for the determination of phosphate in natural waters. Analytica Chimica Acta Volume 27, 1962, Pages 31-36

Özcan, M.M. and Chalchat, J.C. (2006). Chemical composition and antifungal effect of anise (Pimpinella anisum L.) fruit oil at ripening stage. Annals of Microbiology. 2006;56(4):353-358.

Patil N.M., (2010). Biofertilizer Effect on Growth, Protein and Carbohydrate Content in Stevia Rebaudiana Var Bertoni. Recent Research In Science And Technology, 2(10), p: 42-44.

Phillips, J. M. and Hayman, D. S. (1970). Improved procedures for clearing roots and staining parasitic and vesicular-arbuscular mycorrhizal fungi for rapid assessment of infection. Transactions of the British Mycological Society, 55: 157-160.

Pregl, F., (1945). Quantitative Organic Micro Analysis. 4th Edn., J. and A. Churchill Ltd., London.

Ross, I.A. (2001). Medicinal plants of the world: chemical constituents, traditional and modern medicinal uses, Volume 2. Humana press. Totowa, New jersey, pp. 363-374. 
Saber, M. S. and A. M. Gomaa (1993). Associative action of a multi-strain biofertilizer on tomato plants grown in a newly reclaimed soil. The 6th Inter. sympos. on nitrogen fixation with non - legumes, Ismailia, Egypt: 495 - 497.

Salehi S. M. H.(2010). Medicinal Plants and Phytotherapy. Vol. 1. Tehran, Iran: Donyay Taghziah Press; 2010.

Singh, J.S., Pandey, V.C. and Singh, D.P.(2011). Efficient soil microorganisms: a new dimension for sustainable agriculture andenvironmental development. Agric Ecosyst Environ 2011, 140:339-353.

Singh, G.R.; Pandya, K.S.; Choudhary, K.K. and Sharma, R.B. (1997): Biofertilizers in crop production. Indian Farming. 46 (10):34-36.

Skujins, J.and Burns, R.G. (1976). Extracellular enzymes in soil. Crit. Rev. Microbiol. 4, 383-421.

Snedecor, G.W. and Cochran, W.G. (1967) Statistical Methods, 6th ed. Iowa State University Press: Ames.

Snell F. D. and Snell, C. T. (1949). Colorimetric Methods of Analysis. Vol. 2. New York: Van Nostrand; 1949. pp. 802-807.

Snipes, C.E. and Cathey, G.W. (1992). Evaluation of defoliant mixtures in cotton. Field Crops Research 28: 327-334.

Soliman,A.S.; Morsy, E.M. and Massoud, O. N. (2015). Tolerance of bio fertilized Delonix regia seedlings to irrigation intervals. Journal of Horticulture and Forestry. Vol. 7(3), pp. 73-83, March, 2015.

Suke, S.N.,; Deotale, R.D.; Priyanka, H.; Mitali D.; and Sorte,S.N. (2011). Effect of nutrients and biofertilizers of chemical and biochemical parameters of maize (Zea mays L.).J. Soil and Crops, 21(1):107-112.

Thomas, J.C. and Katterman, F.R.; (1986). Cytokinin activity induced by thidiazuron. Plant Physiol. 81: 681-683.

Zargari, A. (1996). Medicinal Plants. Tehran, Iran: Tehran University Press; 1996. 


\section{تأثثير التسميد الحيوى والكيماوى والرش بالTDZ على نمو ومحصول نبات الينسون}

\section{للسادة الدكاترة}

محمد خليل خليل' ، جمال السيد غزال'، عبير محمود'، داليا عبدالحليم سلامجّ

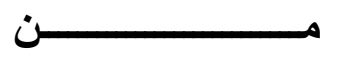

'فرع فسيولوجيا النبات،قسم النبات الزر اعىـ كلية الزر اعه، جامعة القاهرهـ شار ع الجامعهـ الجيزهـ جمهورية مصر العربيه

كَّعبة النباتات الطبيه و المنتجات الطبيعيهـ الهيئه القوميه للرقابه و البحوث الدو ائيه ـــ الجيزهـ جمهورية مصر العربيه

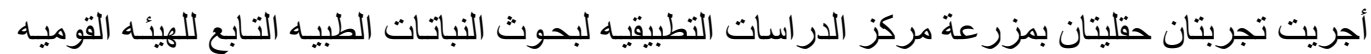

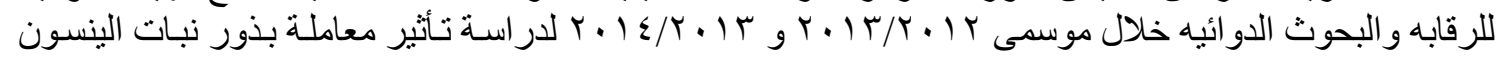

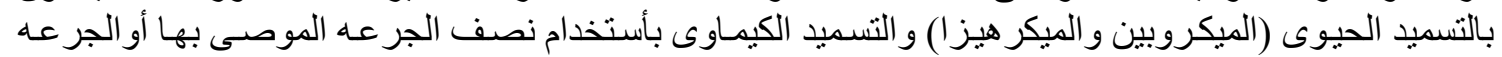

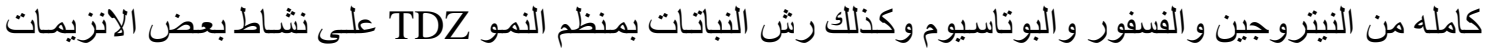

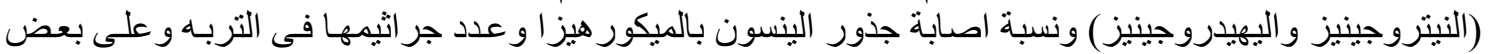

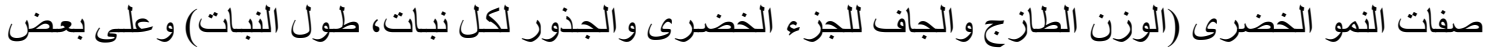

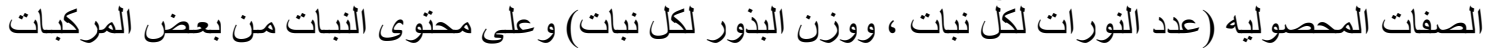

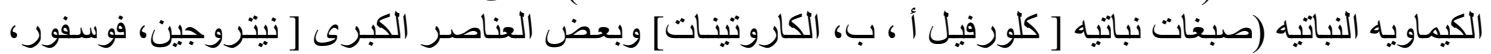

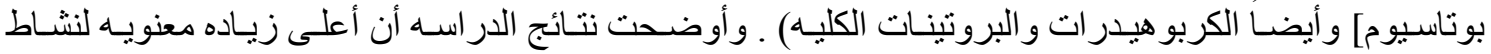

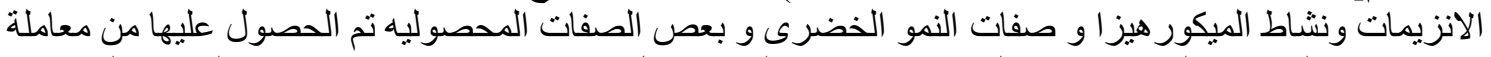

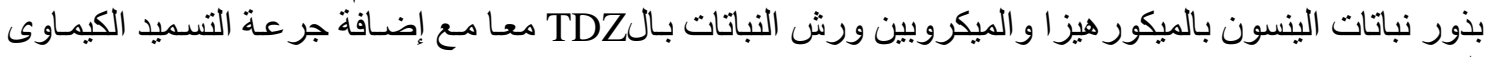

